\title{
Cause specific mortality and cancer incidence among employees exposed to 2,3,7,8-TCDD after a 1953 reactor accident
}

\author{
M Gerald Ott, Andreas Zober
}

\begin{abstract}
Objective-To evaluate the long term health consequences of past occupational exposure to $2,3,7,8$ tetrachlorodibenzo-pdioxin (TCDD).

Methods-Cancer incidence and cause specific mortality were examined up to and including 1992 in a group of 243 men with external comparisons and internal dose-response analyses. Model based estimates of TCDD dose (expressed in $\mu \mathrm{g} / \mathrm{kg}$ body weight) were developed for all cohort members with an approach that incorporated detailed accounts of each employee's work activities, analyses of TCDD in blood lipid of 138 employees, and internally derived estimates of elimination rates of TCDD.
\end{abstract}

Results-The estimated dose of TCDD for 135 men was $\geqslant 0.1 \mu \mathrm{g} / \mathrm{kg}$ body weight and for 69 men $\geqslant 1 \mu g / k g$ body weight. Increased cancer risk ratios were found with higher doses of TCDD and longer interval since first exposure for all sites combined and digestive and respiratory cancers in particular. Within the high dose group ( $\geqslant 1 \mu \mathrm{g} / \mathrm{kg}$ body weight), total cancer mortality was increased $\geqslant 20$ years after first exposure (13 cases, standardised mortality ratio (SMR) 1.97, 95\% confidence interval $(95 \% \mathrm{CI}) 1 \cdot 05-3 \cdot 36)$ as was respiratory cancer (six cases, SMR 3.06; 95\% CI 1-12-6:66). Among current cigarette smokers, 12 cancer deaths occurred in the high dose group (SMR 3.42, 95\% CI 1.77-5.97) compared with seven deaths at lower doses of TCDD (SMR 1.29, 95\% CI $0 \cdot 52-2 \cdot 66)$. Regression analyses based on the Cox's proportional hazards model provided further evidence of a relation between cumulative dose of TCDD and occurrence of both overall and digestive cancer. No evidence of an effect of TCDD on overall mortality or deaths due to circulatory disease was found and no cases of non-Hodgkin's lymphoma or soft tissue sarcoma have been found to date.

Conclusions-Our findings are consistent with a carcinogenic effect induced by TCDD at doses $\geqslant 1 \mu \mathrm{g} / \mathrm{kg}$ body weight. With such a small cohort, the risk estimates are not very stable and could be affected by selection and confounding.

(Occup Environ Med 1996;53:606-612)

Keywords: TCDD; cancer occurrence
Polychlorinated dioxins and furans have been identified as unwanted byproducts of numerous chemical and thermal processes. ${ }^{1}$ The toxic potency of these planar halogenated compounds is well documented and 2,3,7,8tetrachlorodibenzo-p-dioxin (TCDD), the most toxic member of the class, has been shown to cause a wide range of effects including hyperplastic changes in epithelial tissues of the skin, liver, gastric mucosa, bile duct, and urinary bladder. ${ }^{2}$ It is an animal carcinogen and promotes skin, lung, and liver tumours under appropriate experimental conditions. ${ }^{34}$ The mechanisms through which TCDD acts to alter tumour incidence are unknown, but are unlikely to include direct genetic effects. Three recent mortality studies with exposure assessments supported by TCDD measurements in blood, have been interpreted as showing an increased risk of cancer in humans after dioxin exposure. ${ }^{25-7}$ The present investigation updates the mortality experience of one of the three cited studies, ${ }^{7}$ reports cancer incidence for the first time, and examines cancer outcomes in relation to dose of TCDD with more extensive biomonitoring than was previously available.

\section{Materials and methods} STUDY BACKGROUND

On 17 November 1953, an uncontrolled decomposition reaction occurred in a trichlorophenol (TCP) production unit owned by BASF AG and located in Ludwigshafen, Germany. Byproducts that escaped from the damaged autoclave contaminated surfaces throughout the immediate work area of the enclosed production building. Within days, workmen who were engaged in clean up efforts developed severe acne as well as other signs and symptoms and some were taken into hospital. ${ }^{8}$ The agent most likely to have caused these responses was not identified until 1957 when TCDD was chemically shown to be a byproduct $p$ of TCP production and was shown to be a potent acnegen. ${ }^{910}$

Further confirmation that TCDD had been present was provided by biomonitoring data collected more than 30 years after the incident. ${ }^{71}$ These data showed increases of TCDD concentrations in blood lipid that related to both the extent of involvement in clean up activities and an employee's chloracne status. A non-linear regression model relating TCDD concentrations in blood lipid to duration of exposure under various working conditions was developed in 1993. ${ }^{11}$ Concen- 
trations of other dioxin congeners with the possible exception of the 1,2,3,7,8-pentachlorinated congener were not increased and did not correlate with exposure or chloracne status. Most likely, residues from the damaged reactor were the primary, if not the sole, source of TCDD contamination in the unit because of its brief history of operation before the accident (several months) and the decision not to restart TCP operations thereafter. Employees were potentially exposed to residues contaminated with TCDD during the clean up and repair activities that lasted for about 4.5 months, during incidental maintenance work in the building after completion of the restoration work, and finally during demolition of the reactor portion of the building in 1968-9.

Health surveillance of exposed employees has been conducted on a recurring basis since 1953. Descriptive accounts of the signs and symptoms experienced after exposure have been reported as well as laboratory studies correlating biomonitoring data with clinical chemistries, immunological variables, and cytogenetic outcomes; mortality follow up studies; and most recently a long term morbidity study based on medical insurance data have been reported. ${ }^{71-14}$ These investigations identified 115 cases of chloracne ( 56 classified as severe) in a cohort of 254 people. ${ }^{11}$ Most cases were diagnosed during the early clean up period and no severe cases were found after 1959. Up to 1988, a twofold increase in cancer deaths was found $\geqslant 20$ years after first exposure among people with chloracne or erythema. ${ }^{7}$ Clinical investigations and a sickness absenteeism study of this same population have identified the thyroid, immune system, and digestive organs as possible sites of injury induced by TCDD. ${ }^{13-14}$ Findings have included dose-related increases in thyroid disease, infectious and parasitic disease, appendicitis, and chronic liver disease.

\section{STUDY POPULATION AND FOLLOW UP}

Membership in the study cohort was based on evidence of participation in (a) clean up, repair, or activities related to safety in the months after the accident, (b) later repair or maintenance activities, or (c) assisting with the demolition effort in 1968-9. The reporting sources included files from the medical department, written accounts of the clean up activities, interviews with supervisors and coworkers, and voluntary self reports of past potential exposure. Considerable cross validation efforts were undertaken to assure complete ascertainment of the study population. ${ }^{7}$ The present study is based on a cohort of 243 men and four women employees described by Zober et al. ${ }^{7}$ Because there were no known occurrences of cancer among the four women employees and the single death was due to a motor vehicle accident, analyses are based on data for the 243 male employees. Seven additional cohort members identified since the mortality update ${ }^{11}$ are also excluded because cohort eligibility was only established near the end of the follow up period. In this group there has been one death due to unknown causes and one case of bladder cancer diagnosed when cohort eligibility was decided. A subcohort of 69 people ( 68 men, the $C 1$ subcohort) is of particular interest because each member had been diagnosed with chloracne and was included on a list of exposed employees on 5 May 1954.

In the earlier mortality study, vital status to 1988 had been ascertained for all cohort members through company records and contacts with local residents' registration offices. ${ }^{7}$ These same sources were used to trace vital status until 1993. For dead men, copies of death certificates were sought with the assistance of the Berufsgenossenschaft der chemischen Industrie and coded for underlying cause by the 9 th revision of the international classification of diseases (ICD-9). Vital status up to and including 1992 was successfully determined for all cohort members and death certificates were obtained for all but one of the dead workers.

The sources of incident cancer cases were the occupational medical records of employees, death certificate records, doctor's letters, necropsy reports for those who died, and survey results obtained through questionnaires sent to all surviving cohort members. The questionnaire included a consent form to allow diagnostic follow up with the person's personal physician. For non-respondents, a follow up telephone call was made and a second questionnaire sent. The quality and completeness of the diagnostic information could not be evaluated against tumour registry findings as this geographic area is not covered by a tumour registry. Although non-fatal cancers may have been missed in earlier years, recently reported incidences should be complete for most cancer sites. Questionnaire responses or telephone interviews were obtained for all but six people. All self reported cancer diagnoses were confirmed by contacting the private physician supposed to have made the diagnosis.

\section{EXPOSURE ASSESSMENT AND CONCOMITANT} FACTORS

Two distinct indices of past exposure to TCDD were used, the chloracne status of people and the estimated cumulative dose of TCDD expressed in $\mu \mathrm{g} / \mathrm{kg}$ body weight. This measure was derived from an approach described previously. ${ }^{11}$ Several additional steps were required to express the dose in $\mu \mathrm{g} / \mathrm{kg}$ body weight. Firstly, internal estimates of half life of TCDD were derived from repeat sampling of 29 people whose initial TCDD concentrations ranged from 29 to $553 \mathrm{pg} / \mathrm{g}$ blood lipid. The mean half life of $5 \cdot 8$ years found for these people is lower than the $5 \cdot 8$ to $7 \cdot 1$ years reported for other populations exposed to $\mathrm{TCDD}^{15}$ and considerably lower than recent estimates of 10 to 14 years based on data for veterans of Operation Ranch Hand. ${ }^{16}$ Evidence that TCDD half life increases with higher percentages of body fat has been reported in mammals, ${ }^{17}$ and most recently in humans. ${ }^{16}$ This tendency was also found 
within the present population and so individual rates of decay of TCDD were regressed on percentages of body fat to accommodate variable lengths of decay in our procedure of extrapolating back. Percentages of body fat were estimated from body mass index (BMI) as in Wolfe et al. ${ }^{16}$ Our regression model yielded half life estimates of 5.1 and 8.9 years for people with $20 \%$ and $30 \%$ body fat, respectively. In the previous exposure assessment for this cohort, a fixed half life of seven years had been assumed. ${ }^{11}$

Current dioxin body burdens were estimated by multiplying the TCDD concentrations in blood lipid by the estimated total lipid weight for each person assuming a homogeneous distribution of TCDD throughout all fat tissues. This assumption is supported by the work of Patterson et $a l^{15}$ and by limited biopsy and necropsy data for several members of the present cohort. ${ }^{18} \mathrm{~A}$ non-linear regression model was then fitted to find the contribution of duration of exposure under the various work conditions to the TCDD dose, extrapolated back to the time of exposure. ${ }^{11}$ The final step was to calculate a TCDD dose estimate from the model for each cohort member and to divide that quantity by the person's weight at the time of first exposure. A correlation of 0.97 between this measure and the TCDD concentration previously reported by backward extrapolation indicates that either measure would produce similar results in dose-response analyses. Our TCDD dose estimates could be low for employees with the highest exposure intensities if clearance is biphasic at very high levels of intake.

As well as the two TCDD exposure measures, data were collected on age, smoking history, BMI at the time of first exposure, and history of occupational exposure to aromatic amines (namely, $\beta$-naphthylamine) and asbestos. There were 23 people who had reported working with aromatic amines and 16 with asbestos. Of the 23 people with past potential exposure to $\beta$-naphthylamine, 20 had been assigned to a nearby aromatic amine production unit. Potential past exposure to

Table 1 Selected characteristics of 243 male employees included in analyses of data on mortality and cancer incidence

\begin{tabular}{lc}
\hline Characteristic & $n(\%)$ \\
\hline Estimated TCDD dose ( $\mu \mathrm{g} / \mathrm{kg}$ body weight): & $108(44 \cdot 4)$ \\
$<0 \cdot 1$ & $66(27 \cdot 2)$ \\
$0 \cdot 1-0 \cdot 99$ & $47(19 \cdot 3)$ \\
$1 \cdot 0-1 \cdot 99$ & $22(9 \cdot 1)$ \\
$2 \cdot 0+$ & $113(46 \cdot 5)$ \\
Ever diagnosed with chloracne: & $130(53 \cdot 5)$ \\
Yes & $56(23 \cdot 0)$ \\
No & $56(23 \cdot 0)$ \\
Cigarette smoking: & $71(29 \cdot 2)$ \\
Never smoked & $27(11 \cdot 1)$ \\
Former smoker & $33(13 \cdot 6)$ \\
Currently smokes < 1 pack/day & \\
Currently smokes $\geqslant 1$ packs/day & $153(63 \cdot 0)$ \\
Unknown & $75(30 \cdot 9)$ \\
Body mass index at first exposure $\left(\mathrm{kg} / \mathrm{m}^{2}\right):$ & $15(6 \cdot 2)$ \\
$<26$ & $168(69 \cdot 1)$ \\
$26-29 \cdot 9$ & $18(7 \cdot 4)$ \\
$\geqslant 30$ & $57(23 \cdot 5)$ \\
Date of first exposure: & \\
$11 / 17 / 53-11 / 16 / 54$ & \\
$11 / 17 / 54-12 / 31 / 59$ & \\
$01 / 01 / 60-12 / 31 / 68$ & \\
\hline
\end{tabular}

asbestos was determined by job titles or statements made by the employee himself. Smoking histories were available for 210 $(86 \%)$ of the 243 cohort members. Classification of employees by chloracne status has been described previously. ${ }^{11}$ Moderate chloracne was characterised by localised lesions consisting of a few comedones or mild pustules. Severe chloracne consisted of either a generalised chloracne or regional areas of more severe lesions.

\section{STATISTICAL METHODS}

Expected numbers of incident cases of cancer and cause specific deaths were assessed by a modified life table approach. ${ }^{19-20}$ Person years were computed by 5-year age groups and calendar periods and multiplied by external incidence and death rates to derive expected event frequencies. The external death rate data covered the years, 1952-92, for the former West Germany and were provided by the Deutsches Krebsforschungszentrum in Heidelberg. Cancer incidences for the state of Saarland, 1970-91, were used in incidence comparisons. Saarland borders on the Rheinland-Pfalz, which includes Ludwigshafen. Confidence intervals (CIs) for the standardised mortality ratios (SMRs) and standardised incidence ratios (SIRs) were calculated with Poisson distribution assumptions.

Internal dose response analyses were based on the Cox's proportional hazard model with a SAS program (Proc PHREG, SAS Release 6.10). This approach enabled us to include cigarette smoking, BMI, and other potentially confounding exposures in the regression analyses. Occupational exposures to asbestos and aromatic amines were treated as dichotomous variables. The BMI values below $26 \mathrm{~kg} / \mathrm{m}^{2}$ were assigned a score value of 26 . Actual BMI values were used for the remaining people. This was done because increased mortality risks are associated with BMI measurements above $26 \mathrm{~kg} / \mathrm{m}^{2}{ }^{21}$ Smoking data were scored as: 1 (never smoked cigarettes or former cigarette smoker) and 2 (current cigarette smoker). Among the exposure variables only TCDD dose was treated as a time dependent covariate. A stratified analysis approach based on date of first exposure was followed to minimise potential confounding between calendar time and exposure. The three strata were: first exposure within one year of the accident (168 men), first exposure more than one year after the accident and before 1960 (18 men), and first exposure after 1959 (57 men). A stepwise procedure was used in constructing models and results were summarised in terms of conditional risk ratios (CRs) and $95 \%$ CIs.

\section{Results}

Table 1 shows the distribution of cohort members by estimated TCDD dose, chloracne status, cigarette smoking category, and BMI at the time of first exposure. The highest estimated TCDD dose for any person was 8.3 $\mu \mathrm{g} / \mathrm{kg}$ body weight. Among the 243 men, there 
Table 2 Observed deaths (n) and standardised mortality ratios (SMRs) by cause of death and TCDD dose group, $1953-92$

\begin{tabular}{|c|c|c|c|c|c|c|c|c|}
\hline \multirow{2}{*}{$\frac{\text { Cause of death }}{\text { Category }}$} & \multicolumn{2}{|c|}{ Total } & \multicolumn{2}{|c|}{$\begin{array}{l}T C D D<0 \cdot 1 \mu g / \mathrm{kg} \\
\text { body weight }\end{array}$} & \multicolumn{2}{|c|}{$\begin{array}{l}\text { TCDD 0.1-0.99 } \mu \mathrm{g} / \mathrm{kg} \\
\text { body weight }\end{array}$} & \multicolumn{2}{|c|}{$\begin{array}{l}T C D D \geqslant 1 \mu g / k g \\
\text { body weight }\end{array}$} \\
\hline & $n$ & $S M R^{*}(95 \% C I)$ & $n$ & $S M R^{\star}(95 \% C I)$ & $n$ & $S M R^{\star}(95 \% C I)$ & $n$ & $S M R^{\star}(95 \% C I)$ \\
\hline All causes: & 92 & $0.9(0.7$ to 1.1$)$ & 27 & $0.7(0.5$ to 1.0$)$ & 27 & $1.0(0.7$ to 1.5$)$ & 38 & $1.0(0.7$ to 1.4$)$ \\
\hline Malignant neoplasms: & 31 & $1.2(0.8$ to 1.7$)$ & 8 & $0.8(0.4$ to 1.6$)$ & 8 & $1.2(0.5$ to 2.3$)$ & 15 & $1.6(0.9$ to 2.6$)$ \\
\hline Digestive organs & 11 & $1.2(0.6$ to $2 \cdot 1)$ & 2 & $0 \cdot 6(0 \cdot 1$ to $2 \cdot 1)$ & 4 & $1.7(0.5$ to 4.3$)$ & 5 & $1.5(0.5$ to 3.4$)$ \\
\hline Respiratory system & 11 & $1.4(0.7$ to 2.5$)$ & 3 & $1.0(0.2$ to 2.9$)$ & i & $0.5(0.0$ to 2.7$)$ & 7 & $2 \cdot 4(1.0$ to $5 \cdot 0)$ \\
\hline Prostate & 0 & $0.0(0.0$ to 1.9$)$ & 0 & $0.0(0.0$ to 5.7$)$ & 0 & $0.0(0.0$ to 7.5$)$ & 0 & $0.0(0.0$ to 4.6$)$ \\
\hline Bladder or kidney & 2 & $1.1(0.1$ to 4.0$)$ & 0 & $0.0(0.0$ to 5.7$)$ & 2 & $4 \cdot 1(0.5$ to 14.7$)$ & 0 & $0.0(0.0$ to 5.4$)$ \\
\hline Lymphatic or haematopoietic tissue & 2 & $1.2(0.2$ to 4.5$)$ & 1 & $1.6(0.0$ to 9.1$)$ & 0 & $0.0(0.0$ to 8.4$)$ & 1 & $1.8(0.0$ to 9.8$)$ \\
\hline Residual sites & 5 & $1.6(0.5$ to 3.6$)$ & 2 & $1.6(0.2$ to 5.7$)$ & 1 & $1.2(0.0$ to 6.4$)$ & 2 & $1.9(0.2$ to 6.7$)$ \\
\hline Diseases of circulatory system: & 37 & $0.8(0.6$ to 1.2$)$ & 13 & $0.8(0.4$ to 1.4$)$ & 11 & $1.0(0.5$ to 1.7$)$ & 13 & $0.8(0.4$ to 1.3$)$ \\
\hline Ischaemic heart disease & 16 & $0.7(0.4$ to 1.1$)$ & 7 & $0.9(0.3$ to 1.8$)$ & 4 & $0.7(0.2$ to 1.7$)$ & 5 & $0.6(0.2$ to 1.3$)$ \\
\hline Diseases of respiratory system & 1 & $0.1(0.0$ to 0.8$)$ & 0 & $0.0(0.0$ to 1.5$)$ & 0 & $0.0(0.0$ to 2.1$)$ & 1 & $0.4(0.0$ to 2.0$)$ \\
\hline Diseases of digestive system & 5 & $0.7(0.2$ to 1.7$)$ & 0 & $0.0(0.0$ to 1.4$)$ & 1 & $0.5(0.0$ to 3.0$)$ & 4 & $1.6(0.4$ to 4.2$)$ \\
\hline External causes: & 13 & $1.7(0.9$ to 2.9$)$ & 4 & $1.3(0.4$ to 3.3$)$ & 6 & $2.7(1.0$ to 5.9$)$ & 3 & $1.3(0.2$ to 3.7$)$ \\
\hline Suicide & 6 & $2.2(0.8$ to 4.7$)$ & 1 & $0.9(0.0$ to 4.9$)$ & 4 & $5 \cdot 1(1 \cdot 4$ to $13 \cdot 1)$ & 1 & $1.2(0.0$ to 6.6$)$ \\
\hline Residual causes of death & 5 & $0.4(0.1$ to 1.0$)$ & 2 & $0.5(0.1$ to 1.7$)$ & i & $0.3(0.0$ to 1.8$)$ & 2 & $0.5(0.1$ to 1.7$)$ \\
\hline
\end{tabular}

`Expected deaths based on age, sex, and calendar period specific death rates for the former West Germany, $1952-92$.

were 113 cases of chloracne diagnosed with 55 being classified as severe.

\section{MORTALITY UPDATE}

Between 1988 and 1992, 15 deaths were observed $v 22.7$ expected. There were eight cancer deaths $(6 \cdot 3$ expected). Table 2 shows the cause specific mortality for the total cohort and three TCDD dose subgroups over the entire follow up period, 1953-92. In general somewhat higher risk ratios were found with increasing dose of TCDD for total malignant neoplasms and for digestive and respiratory cancer in particular. Three of the deaths from digestive cancer occurred at doses $>4 \mu \mathrm{g} / \mathrm{kg}$ body weight $(0.33$ expected). There were also four observed $v 2.4$ expected deaths due to diseases of the digestive system in the high TCDD dose group (these deaths were all due to cirrhosis of the liver) and four observed $v$ 0.8 expected deaths due to suicide in the middle TCDD dose group. There were no deaths due to infectious and parasitic diseases (1.5 expected).

Higher SMRs for cancer were also found with increasing interval since first exposure. There were no cancer deaths during the first 10 years after exposure, seven observed $v 6 \cdot 0$ expected between 10 and 19 years after first exposure and 24 observed $v 17 \cdot 3$ expected $\geqslant 20$ years after first exposure. The excess in this category is accounted for by the 13 observed $v 6.6$ expected cancer deaths (SMR $1.97,95 \%$ CI $1.05-3.36)$ in the high TCDD dose subgroup. Six of these deaths were due to respiratory cancer (SMR 3.06, 95\% $1 \cdot 12-6 \cdot 66)$.

Separate mortality analyses were conducted for the subset of 113 men with chloracne. Overall there were 54 observed $v \quad 54.9$ expected deaths and 20 observed $v 12.5$ expected cancer deaths. For the period $\geqslant 20$ years after first exposure there were 18 cancer deaths (SMR 1.90, 95\% CI 1.13-3.00). Six of these deaths were due to cancers of the digestive organs (SMR 1.83, 95\% CI $0 \cdot 67-3 \cdot 98$ ) and seven were respiratory cancers (SMR $2 \cdot 42,95 \%$ CI $0.97-4.99$ ). The mortality experience within the severe chloracne subgroup was more favourable than for the chloracne group as a whole. For example, $\geqslant 20$ years after first exposure there were five observed $v$ $5 \cdot 2$ expected cancer deaths. Overall mortality was also lower in the severe chloracne subgroup (22 observed $v 30.5$ expected deaths) than in the moderate chloracne subgroup ( 32 observed $v 24.4$ expected deaths).

Mortality experience within the C1 subcohort parallels that found for the total cohort with 34 observed $v 35.8$ expected deaths. Cancer mortality was only marginally increased ( 12 observed $v 8.8$ expected deaths); however, 10 of the cancer deaths (5.9 expected) occurred among people whose TCDD dose estimates exceeded $1 \mu \mathrm{g} / \mathrm{kg}$ body weight. The six digestive cancers $(3 \cdot 2$ expected) included three deaths from stomach cancer $(1 \cdot 2$ expected). Individual dose estimates for the five respiratory cancer deaths were all above $1 \mu \mathrm{g} / \mathrm{kg}$ body weight.

Table 3 Observed cases (n) and standardised incidence ratios (SIRs) by primary site cancer and TCDD dose group, 1960-92

\begin{tabular}{|c|c|c|c|c|c|c|c|c|}
\hline \multirow[b]{2}{*}{ Primary cancer site } & \multicolumn{2}{|c|}{ Total } & \multicolumn{2}{|c|}{$\begin{array}{l}T C D D<0.1 \mu g / k g \\
\text { body weight }\end{array}$} & \multicolumn{2}{|c|}{$\begin{array}{l}\text { TCDD } 0.1-0.99 \mu g / k g \\
\text { body weight }\end{array}$} & \multicolumn{2}{|c|}{$\begin{array}{l}T C D D \geqslant 1 \mu g / k g \\
\text { body weight }\end{array}$} \\
\hline & $n$ & $S I R^{*}(95 \% C I)$ & $n$ & $S I R^{*}(95 \% C I)$ & $n$ & $S I R^{\star}(95 \% C I)$ & $n$ & $S I R^{*}(95 \% C I)$ \\
\hline $\begin{array}{l}\text { All sites: } \\
\text { Buccal cavity } \\
\text { Digestive organs } \\
\text { Stomach } \\
\text { Colorectal } \\
\text { Liver, gall bladder, or bile duct } \\
\text { Respiratory system } \\
\text { Lung or bronchus } \\
\text { Skin including melanoma } \\
\text { Prostate } \\
\text { Bladder or kidney } \\
\text { Lymphatic or haematopoietic tissue } \\
\text { Residual }\end{array}$ & $\begin{array}{r}47 \\
2 \\
12 \\
3 \\
5 \\
2 \\
13 \\
11 \\
5 \\
4 \\
5 \\
2 \\
2\end{array}$ & $\begin{array}{l}1.2(0.8 \text { to } 1.5) \\
1.2(0.1 \text { to } 4.4) \\
1.1(0.6 \text { to } 1.9) \\
1.0(0.2 \text { to } 2.9) \\
1.0(0.3 \text { to } 2.3) \\
2.1(03 \text { to } 7.5) \\
1.2(0.6 \text { to } 2.0) \\
1.1(0.6 \text { to } 2 \cdot 0) \\
1.2(0.4 \text { to } 2 \cdot 8) \\
1.1(0.3 \text { to } 2 \cdot 8) \\
1.4(0.4 \text { to } 3.2) \\
1.0(0.1 \text { to } 3.5) \\
1.2(0.3 \text { to } 3.1)\end{array}$ & $\begin{array}{r}15 \\
2 \\
3 \\
0 \\
2 \\
1 \\
1 \\
1 \\
1 \\
3 \\
1 \\
1 \\
1\end{array}$ & $\begin{array}{l}1.0(0.5 \text { to } 1.6) \\
2.6(0.3 \text { to } 9.5) \\
0.7(0.2 \text { to } 2.2) \\
0.0(0.0 \text { to } 3.4) \\
1.1(0.1 \text { to } 3.9) \\
2.8(0.1 \text { to } 15.5) \\
0.7(0.2 \text { to } 2.1) \\
0.3(0.0 \text { to } 1.5) \\
0.6(0.0 \text { to } 3.3) \\
2.5(0.5 \text { to } 7.4) \\
0.7(0.0 \text { to } 4.0) \\
1.2(0.0 \text { to } 6.8) \\
0.8(0.0 \text { to } 4.4)\end{array}$ & $\begin{array}{r}13 \\
0 \\
4 \\
1 \\
2 \\
0 \\
2 \\
2 \\
2 \\
1 \\
3 \\
0 \\
1\end{array}$ & $\begin{array}{l}1.2(0.6 \text { to } 2 \cdot 1) \\
0.0(0.0 \text { to } 8.8) \\
1.4(0.4 \text { to } 3.6) \\
1.3(0.0 \text { to } 7.0) \\
1.4(0.2 \text { to } 5.1) \\
0.0(0.0 \text { to } 15.4) \\
0.7(0.1 \text { to } 2.5) \\
0.8(0.1 \text { to } 2.8) \\
1.8(0.2 \text { to } 6.5) \\
1.1(0.0 \text { to } 5.9) \\
3.0(0.6 \text { to } 8.9) \\
0.0(0.0 \text { to } 6.6) \\
1.1(0.0 \text { to } 6.0)\end{array}$ & $\begin{array}{r}19 \\
0 \\
5 \\
2 \\
1 \\
1 \\
8 \\
8 \\
2 \\
0 \\
1 \\
1 \\
2\end{array}$ & $\begin{array}{l}1.3(0.8 \text { to } 2.0) \\
0.0(0.0 \text { to } 8.0) \\
1.2(0.4 \text { to } 2.9) \\
1.7(0.2 \text { to } 6.2) \\
0.5(0.0 \text { to } 3.0) \\
2.8(0.1 \text { to } 15.5) \\
2.0(0.9 \text { to } 3.9) \\
2.2(1.0 \text { to } 4.3) \\
1.5(0.2 \text { to } 5.3) \\
0.0(0.0 \text { to } 2.5) \\
0.8(0.0 \text { to } 4.4) \\
1.4(0.0 \text { to } 8.0) \\
1.7(0.2 \text { to } 5.8)\end{array}$ \\
\hline
\end{tabular}

${ }^{\star}$ Expected incident cases calculated based on age, sex, and calendar period specific cancer incidence rates for Saarland, $1970-91$. 
Table 4 Results of Cox's regression analyses for selected cause of death and cancer incidence outcomes up to 1993, stratification by first exposure date *

\begin{tabular}{|c|c|c|c|c|}
\hline & $T C D D$ ( $\mu g / k g$ body weight) & Age (y) & Smoking cigarettest & $B M I\left(\mathrm{~kg} / \mathrm{m}^{2}\right)$ \\
\hline Health outcome & CR $(95 \% C I)$ & $C R(95 \% C I)$ & $C R(95 \% C I)$ & $C R(95 \% C I)$ \\
\hline $\begin{array}{l}\text { Non-cancer deaths: } \\
\text { All causes }(n=92) \\
\text { Diseases of circulatory system }(n=37) \\
\text { Cancer outcomes: }\end{array}$ & $\begin{array}{l}1.03(0.88 \text { to } 1.22) \\
0.93(0.70 \text { to } 1.24)\end{array}$ & $\begin{array}{l}1.09(1.07 \text { to } 1.12) \\
1.11(1.08 \text { to } 1.15)\end{array}$ & $2 \cdot 22(1.44$ to $3 \cdot 42)$ & $\begin{array}{l}1.16(1.01 \text { to } 1.33) \\
1.21(1.01 \text { to } 1.44)\end{array}$ \\
\hline $\begin{array}{l}\text { Cancer outcomes: } \\
\text { All sites: }\end{array}$ & & & & \\
\hline $\begin{array}{l}\text { As cause of death }(n=31) \\
\text { Incidence cases }(n=47)\end{array}$ & $\begin{array}{l}1.22(1.00 \text { to } 1.50) \\
1.11(0.91 \text { to } 1.35)\end{array}$ & $\begin{array}{l}1.10(1.06 \text { to } 1.14) \\
1.06(1.03 \text { to } 1.09)\end{array}$ & $\begin{array}{l}3.34(1.59 \text { to } 7.03) \\
2.32(1.29 \text { to } 4.15)\end{array}$ & 二 \\
\hline $\begin{array}{l}\text { Digestive cancer: } \\
\text { As cause of death }(n=11) \\
\text { Incidence cases }(n=12)\end{array}$ & $\begin{array}{l}1.46(1.13 \text { to } 1.89) \\
1.39(1.07 \text { to } 1.69)\end{array}$ & $\begin{array}{l}1 \cdot 10(1.03 \text { to } 1 \cdot 17) \\
1.10(1.04 \text { to } 1 \cdot 16)\end{array}$ & - & $\overline{-}$ \\
\hline $\begin{array}{l}\text { Respiratory cancer: } \\
\text { As cause of death }(n=11) \\
\text { Incidence cases }(n=13)\end{array}$ & $\begin{array}{l}1.09(0.70 \text { to } 1.68) \\
1.02(0.65 \text { to } 1.59)\end{array}$ & $\begin{array}{l}1.09(1.02 \text { to } 1.16) \\
1.07(1.01 \text { to } 1.13)\end{array}$ & $\begin{array}{l}5.33(1.38 \text { to } 20.5) \\
4.39(1.33 \text { to } 14.5)\end{array}$ & - \\
\hline $\begin{array}{l}\text { All other cancer: } \\
\text { As cause of death }(n=9) \\
\text { Incidence cases }(n=22)\end{array}$ & $\begin{array}{l}0.90(0.50 \text { to } 1.63) \\
0.90(0.59 \text { to } 1.36)\end{array}$ & $1.09(1.03$ to 1.17$)$ & 二 & $\overline{1.49}(1.15$ to 1.94$)$ \\
\hline
\end{tabular}

*TCDD forced into model; covariates entered at the 0.20 level and retained at the 0.05 level (no interaction terms were used in model). †Smoking scored as: $1=$ never smoked or former smoker, $2=$ current smoker; 33 men with unknown smoking history were scored as 1 .

CANCER INCIDENCE

Table 3 shows the cancer incidences by TCDD dose. There were 16 additional cancer cases identified that had not been coded as underlying cause of death. Although Saarland and not all of West Germany is the source of external cancer incidences, the difference between expected cancer incidence and expected mortality of 15.3 is close to the 16 additional cancers identified. This same pattern was true across TCDD subgroups. There was a gain of three respiratory and digestive cancers, five skin cancers including one melanoma, four prostate cancers, three bladder cancers and one case of testicular cancer. Three of the four prostate cancers occurred in the lowest TCDD dose group. Four of the five skin cancers occurred in the two highest dose groups. The standardised incidence ratio (SIR) for cancer of the lung and bronchus was increased in the high dose group (eight cases, SIR 2.20, 95\% CI 0.95-4.34). Among the 23 people with past exposure to $\beta$-naphthylamine there were four urinary tract cancers (SIR $6 \cdot 90,95 \%$ CI $1 \cdot 88-17 \cdot 7)$. There have been no connective or other soft tissue cancers observed to date $(0.23$ expected).

\section{INTERNAL ANALYSES}

Table 4 shows the Cox's regression results. Cigarette smoking was significantly related to overall mortality, to total cancer mortality and incidence, and to respiratory cancer mortality and incidence. Cigarette smoking was also marginally related to deaths from circulatory disease (CR 1.46, 95\% CI 0.95-2.25). The BMI was significantly related to total mortality, deaths due to circulatory disease, and other incident cases of cancer. Exposure to aromatic amines ( $\beta$-naphthylamine) was mar- ginally related to other incident cases of cancer

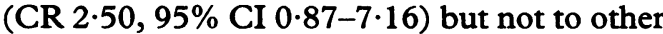
outcomes. Past asbestos exposure was not a significant predictor of any health outcome. There had been one death due to mesothelioma in an employee with past asbestos exposure whose TCDD dose was less than 0.1 $\mu \mathrm{g} / \mathrm{kg}$ body weight.

The TCDD dose was not related to either deaths due to all causes or deaths due to circulatory disease. There was an increase in overall cancer mortality with higher TCDD dose and significantly increased risk ratios for digestive cancer, but not for respiratory cancer. The conditional risk was expressed as the risk per unit ( $1 \mu \mathrm{g} / \mathrm{kg}$ body weight) increase in TCDD dose. Review of the digestive cancer cases showed that three cases had occurred among the four most exposed employees in the entire cohort. The primary tumour sites were liver (TCDD dose estimate, $8.3 \mu \mathrm{g} / \mathrm{kg}$ body weight), stomach (TCDD dose estimate $6.8 \mu \mathrm{g} / \mathrm{kg}$ body weight), and pancreas (TCDD dose estimate $6 \cdot 1 \mu \mathrm{g} / \mathrm{kg}$ body weight). The highest TCDD dose estimate for any respiratory cancer was $2.4 \mu \mathrm{g} / \mathrm{kg}$ body weight. Analyses with chloracne status as an exposure surrogate instead of TCDD dose were unremarkable.

DOSE OF TCDD AND CIGARETTE SMOKING

Additional SMR analyses were performed to examine the joint effects of TCDD and cigarette smoking on cancer outcomes. The pattern of observed and expected cancer deaths suggests a positive dose-response gradient for TCDD among active cigarette smokers but not among non-smokers (table 5). Twelve of the cancer deaths ( 3.5 expected deaths with general population death rates) occurred

Table 5 Observed deaths and standardised mortality ratios (SMRs) for deaths due to total malignant neoplasms by TCDD dose and cigarette smoking, 1953-92

\begin{tabular}{|c|c|c|c|c|c|c|c|c|c|}
\hline \multirow[b]{2}{*}{$T C D D$ dose ( $\mu g / k g$ body weight) } & \multirow[b]{2}{*}{ Men } & \multicolumn{2}{|c|}{ Total deaths } & \multicolumn{2}{|c|}{ Non or ex-smoker } & \multicolumn{2}{|c|}{ Current smoker } & \multicolumn{2}{|c|}{ Unknown } \\
\hline & & $n$ & $S M R^{*}(95 \% C I)$ & $n$ & $S M R^{*}(95 \% C I)$ & $n$ & $S M R^{*}(95 \% C I)$ & $n$ & $S M R^{*}(95 \% C I)$ \\
\hline $\begin{array}{c}\text { Total group: } \\
<0 \cdot 10 \\
0 \cdot 10-0.99 \\
1.0-1.99 \\
\geqslant 2.00\end{array}$ & $\begin{array}{r}243 \\
108 \\
66 \\
47 \\
22\end{array}$ & $\begin{array}{r}31 \\
8 \\
8 \\
8 \\
7\end{array}$ & $\begin{array}{l}1.2(0.8 \text { to } 1.7) \\
0.8(0.4 \text { to } 1.6) \\
1.2(0.5 \text { to } 2.3) \\
1.4(0.6 \text { to } 2.7) \\
2.0(0.8 \text { to } 4.0)\end{array}$ & $\begin{array}{l}8 \\
2 \\
3 \\
2 \\
1\end{array}$ & $\begin{array}{l}0.7(0.3 \text { to } 1.4) \\
0.5(0.1 \text { to } 1.7) \\
0.9(0.2 \text { to } 2.6) \\
0.9(0.1 \text { to } 3.3) \\
0.8(0.0 \text { to } 4.5)\end{array}$ & $\begin{array}{r}19 \\
4 \\
3 \\
6 \\
6\end{array}$ & $\begin{array}{l}2.1(1.3 \text { to } 3.3) \\
1.2(0.3 \text { to } 3.1) \\
1.4(0.3 \text { to } 4.2) \\
3.0(1.1 \text { to } 6.5) \\
4.0(1.5 \text { to } 8.6)\end{array}$ & $\begin{array}{l}4 \\
2 \\
2 \\
0 \\
0\end{array}$ & $\begin{array}{l}0.7(0.2 \text { to } 1.8) \\
1.1(0.1 \text { to } 3.8) \\
1.4(0.1 \text { to } 5.2) \\
0.0(0.0 \text { to } 2.1) \\
0.0(0.0 \text { to } 4.5)\end{array}$ \\
\hline
\end{tabular}

¿Expected deaths calculated based on age, sex, and calendar period specific death rates for the former West Germany, $1952-92$. 
among people with TCDD dose estimates above $1 \mu \mathrm{g} / \mathrm{kg}$ body weight. Five of these deaths were due to lung cancer, four were due to digestive cancers (two stomach), and two were due to cancers of ill defined sites. Cox's regression analyses within the subgroup of 98 current cigarette smokers showed increased conditional risk ratios with TCDD dose for total and digestive cancer mortality and incidence. For total cancer mortality the TCDD conditional risk ratio was $1.43(95 \% \mathrm{CI}$ $1 \cdot 13-1 \cdot 81$ ).

\section{Discussion}

Before the availability of analyses for TCDD in blood lipid, surveillance of this accident population was hindered by difficulties in defining the population at risk and in characterising exposure intensities. The reasons for this were several. Firstly, most people participating in the clean up and evaluation activities were not regular employees of the production unit itself; hence, their presence in the affected work area was not necessarily noted at the time of the accident unless signs of ill health were reported. Although it was not known then, brief work assignments in the autoclave room could result in substantial exposure to TCDD. Another problem was that the impact of safety precautions could not be fully evaluated without biomonitoring data. It was not known, for example, that safety measures instituted during the 1968-9 demolition activities had been effective in minimising any potential for TCDD exposure. In the present update, the assessment of exposure was facilitated by knowledge of the toxicokinetic and metabolic properties of TCDD, by detailed descriptions of each employee's accident related work activities, and by the availability of TCDD biomonitoring data for more than $50 \%$ of the cohort members.

\section{OVERALL MORTALITY}

For all causes of death combined and for deaths due to diseases of the circulatory system, we found increased risk ratios relative to both cigarette smoking and BMI but not relative to TCDD dose nor chloracne status. Although indications of various health effects related to TCDD have been reported within this study population, ${ }^{511-12}$ longevity and circulatory disease outcomes do not seem to be measurably affected at these exposure burdens.

\section{CANCER OUTCOMES}

There is at least suggestive evidence that TCDD affects the occurrence of overall cancer and respiratory and digestive cancer risks in particular. Joint analyses of TCDD dose and cigarette smoking indicate that this doseresponse trend was primarily a reflection of a strong positive trend among men who reported smoking cigarettes. Another key finding in favour of a TCDD effect is the higher than expected cancer mortality $\geqslant 20$ years after first exposure in the high dose group (external analyses).
The case for respiratory cancer rests primarily on the external comparisons, which showed more deaths from respiratory cancer than expected in the high TCDD dose group. Among the 11 cases of lung cancer only one reported having never smoked cigarettes. The reported histology of this case was large cell carcinoma and the estimated TCDD dose was $1.4 \mu \mathrm{g} / \mathrm{kg}$ body weight. All other cases had smoked cigarettes although only three reported heavy cigarette smoking. Review of histology data for nine cases suggests that small cell carcinoma (five cases) was somewhat more prevalent than in other case series. ${ }^{22}$ Although we previously found an increased rate of absenteeism due to upper respiratory tract infections, episodes of pneumonia and chronic obstructive lung disease were not notably increased ${ }^{13}$ and deaths due to respiratory disease were significantly below expectation in the total cohort. Given that most lung cancer cases occurred among known cigarette smokers, it would seem that any effect related to TCDD is indirect; however, the lack of a TCDD dose-response trend among non-smokers could also be a consequence of small sample size.

For digestive cancer, there was about a $50 \%$ increase in deaths among people with a TCDD dose above $0.1 \mu \mathrm{g} / \mathrm{kg}$ body weight based on nine cases. There was no dominant cancer site; however, there were three deaths from stomach cancer and the death from hepatocellular carcinoma occurred in the person with the highest estimated TCDD dose. Two additional cases of stomach cancer were identified during 1993 and 1994, one in the intermediate and one in the high dose group. Four of the five known cases of stomach cancer have been members of the $\mathrm{C} 1$ subcohort and three had estimated TCDD doses above $1 \mu \mathrm{g} / \mathrm{kg}$ body weight. One other person in the C1 subcohort, who had died in 1967 due to cardiovascular disease and whose estimated TCDD dose was $1.3 \mu \mathrm{g} / \mathrm{kg}$ body weight, was suspected of having a malignant tumour of the stomach. The earlier morbidity study had identified a significantly higher occurrence of appendicitis before 1970 among people exposed to TCDD relative to controls and higher rates of gastritis and duodenitis in relation to TCDD exposure; the occurrence of gastric or duodenal ulcers was not related to TCDD exposure. ${ }^{13}$ Studies in rats have established that TCDD exposure induces a delayed onset hypergastrinaemia possibly mediated through decreased gastric acid secretion. ${ }^{23}$

Surveillance of this population is ongoing and thus continues to provide new facts on both the exposure and health status of employees. Recently, blood specimens for TCDD analysis were provided by three more cohort members. For one of the men, the TCDD concentration of $237 \mathrm{pg} / \mathrm{g}$ blood lipid in 1995 was much higher than predicted by our regression model. In a follow up interview, this person described a previously unknown incident in which he had been exposed to a soot cloud released during work on the damaged autoclave two days after the accident. He subse- 
quently developed severe chloracne and lost time from work due to illness, both of which were documented in the medical records. In 1960, he was treated for appendicitis. Currently, he shows no active acnegenic lesions or evidence of scaring and he has never smoked cigarettes or been diagnosed with cancer.

Our overall findings are consistent with an increase in cancer risks induced by TCDD in people with past TCDD exposures sufficient to produce other signs of toxicity. A positive dose-response gradient was evident among cigarette smokers, but not among non-smokers. Unfortunately, with such a small cohort, the risk estimates are not very stable and we are unable to assess whether TCDD might be exerting an influence independent of other cancer risk factors.

The strengths of this study include the exposure assessment, the nearly 40 year follow up period, an extensive clinical data base supporting our health outcome assessment, and the availability of cigarette smoking histories for most people. Limitations stem from the small size of the study population, the possibility of unknown confounding exposures, and the potential for biases in reporting illness and detecting diagnoses that is linked to the considerable medical attention received by cohort members over the years

We thank Professor Harvey Checkoway, Seattle, Washington, USA, for his comments and suggestions regarding our draft manuscript.

1 World Health Organisation Task Group on Chlorinated Dibenzo-p-dioxins and Dibenzofurans. Polychlorinated dibenzo-para-dioxins and dibenzofurans. Geneva: WHO, 1989:39-60.(Environmental Health Criteria 88.)

2 Birnbaum LS. The mechanism of dioxin toxicity: relationship to risk assessment. Environ Health Perspect 1994; 102:157-67.

3 Huff J. 2,3,7,8-TCDD: a potent and complete carcinogen in experimental animals. Chemosphere 1992;25:173-6.

4 Beebe LE, Anver MR, Riggs CW, Fornwald LW, Anderson LM. Promotion of $\mathrm{N}$-nitrosodimethylamineinitiated mouse lung tumors following single or multiple low dose exposure to 2,3,7,8-tetrachlorodibenzop-dioxin. Carcinogenesis 1995;16:1345-9.
5 Fingerhut MA, Halperin WE, Marlow DA, Piacitelli LA, Honchar PA, Sweeney MH, et al. Cancer mortality in workers exposed to 2,3,7,8-tetrachlorodibenzo-p-dioxin N Engl F Med 1991;324:212-8.

6 Manz A, Berger J, Dwyer JH, Flesch-Janys D, Nagel S Waltsgott $\mathrm{H}$. Cancer mortality among workers in chemical plant contaminated with dioxin. Lancet 1991;338: 959-64.

7 Zober A, Messerer P, Huber P. Thirty-four-year mortality follow-up of BASF employees exposed to 2,3,7,8-TCDD after the 1953 accident. Int Arch Occup Environ Health 1990;62:139-57.

8 Goldmann P. Schwerste akute Chlorakne durch Trichlorphenol-Zersetzungsprodukte. Arbeitsmedizin Trichlorphenol-Zersetzungsprodukte.

9 Schulz KH. Klinische und experimentelle Untersuchungen zurtiologie der Chlorakne. Archive für Klinische und Experimentelle Dermatologie 1957;206:589-96.

10 Kimmig J, Schulz KH. Chlorierte aromatische zyklische Aether als Ursache der sogenannten Chlorakne. Naturwissenschaften 1957;44:337-8.

11 Ott MG, Messerer P, Zober A. Assessment of past occupational exposure to 2,3,7,8-tetrachlorodibenzo-p-dioxin using blood lipid analyses. Int Arch Occup Environ Health 1993;65:1-8.

12 Zober A, Ott MG, Fleig I, Heidemann A. Cytogenetic studies in lymphocytes of workers exposed to 2,3,7,8-

13 Zober A, Ott MG, Messerer P. Morbidity follow-up study of BASF employees exposed to 2,3,7,8-TCDD after a 1953 chemical reactor accident. Occup Environ Med 1994;51 479-86.

14 Ott MG, Zober A, Germann C. Laboratory results for selected target organs in 138 individuals occupationally exposed to TCDD. Chemosphere 1994;29:2423-37.

15 Patterson DG, Fingerhut MA, Roberts DW, Needham LL Sweeney MH, Marlow DA, et al. Levels of polychlorinated dibenzo-p-dioxins and dibenzofurans in workers exposed to 2,3,7,8-tetrachlorodibenzo-p-dioxin. Am Ind Med 1989;16:135-46.

16 Wolfe WH, Michalek JE, Miner JC, Pirkle JL, Caudill SP Patterson DG, Needham LL. Determinants of TCDD half-life in veterans of Operation Ranch Hand. $₹$ Toxicol Environ Health 1994;41:481-8.

17 Geyer H, Scheuntert I, Rapp K, Kettrup A, Korte F, Greim H, Rozman K. Correlation between acute toxicity of 2,3,7,8-tetrachlorodibenzo-p-dioxin (TCDD) and of 2,3,7,8-tetrachlorodibenzo-p-dioxin (TCDD) and 97-107.

18 Zober A, Päpke O. Concentrations of PCDDs and PCDFs in human tissue 36 years after accidental dioxin exposure. Chemosphere 1993;27:413-8.

19 Hill ID. Computing man years at risk. Br $\mathrm{f}$ Prev Soc Med 1972;26:132-4.

20 Monson RR. Analysis of relative survival and proportional mortality. Comp Biomed Res 1974;7:325-32.

21 Lee IM, Manson JE, Hennekens H, Paffenbarger RS. Body weight and mortality. A 27 -year follow-up of middleweight and mortality. A 27-year foll

22 Colby TV, Koss MN, Travis, WD. Tumors of the lower respiratory tract. In: Atlas of tumor pathology, third series respiratory tract. In: Atlas of tumor pathology, third series fascicle 13. Washington, DC: Armed Forces

23 Mably TA, Theobald HM, Ingall GB, Peterson RE. Hypergastrinemia is associated with decreased gastric acid secretion in 2,3,7,8-tetrachlordibenzo-p-dioxin treated rats. Toxicol Appl Pharmacol 1990;106:518-28.

\section{Occupational and Environmental Medicine and the electronic age}

OEM has an Email address which is 100632.3615@compuserve.com. We welcome contact by Email, including letters to the editor. Some of our reviewers already send us their reports by Email, helping to speed up the peer review process.

We are moving towards electronic publishing and for some months now we have been asking authors to send us their revised papers on disk as well as a hard copy. I am delighted to report that nearly all our authors are managing to comply with this request; far more than for other specialist journals in the BMJ Publishing group. Oddly enough, the few authors who have not sent us a disk version of their revised papers have been almost exclusively from the United Kingdom. I would be interested in suggestions for why this might be. Perhaps United Kingdom based authors read our correspondence and instructions less assiduously? Watch for revised Instructions to Authors.

The Editor 